ISSN 2303-0992

ISSN online 2621-3176

Jurnal Matematika dan Pembelajaran

Volume 7, No. 1, Juni 2019, h. 50-64

\title{
TRANSLATION BETWEEN MATHEMATICAL REPRESENTATION: HOW STUDENTS UNPACK SOURCE REPRESENTATION?
}

\author{
Dwi Rahmawati \\ Universitas Muhammadiyah Metro \\ dwirahmawati1083@gmail.com
}

\begin{abstract}
Abstrak
Penelitian ini bertujuan untuk memeriksa aktrivitas mahasiswa pada tahap unpack the source ketika melakukan translasi representasi verbal ke grafik. Penelitian ini merupakan penelitian deskriptif kualitatif. Subjek penelitian ini adalah 20 mahasiswa pendidikan matematika. Data dikumpulkan melalui tes disertai think aloud. Hasil penelitian menunjukkan bahwa aktivitas mahasiswa dalam membongkar sumber (unpack the source) adalah membaca masalah dengan teliti, menggambar skema dari situasi verbal, mengidentifikasi hal yang diketahui, mengidentifikasi hal yang ditanyakan, meninterpretasi informasi dan mengidentifikasi informasi baru.
\end{abstract}

Kata kunci: Tranlasi, Representasi, Unpack

\begin{abstract}
This study aimed to examine the activity of students in unpacking the source during the translation process of verbal to the graph representations. This research was a qualitative descriptive study. Subject of this study are twenty students of mathematics education program. The data were collected through the think-aloud test. The results showed that the activities of students in unpacking the source are reading the questions carefully, drawing the scheme of the verbal situation, identifying the things that are known, identifying the things that are asked, interpreting information and identifying new information. Schemes facilitate students in unpacking the source. The results of this research can be used as consideration to minimize the difficulties of students in unpacking the source when performing translation of verbal to the graph representation. This research is also limited to the representation translation from verbal to graph representation, has not examined the other representation such as verbal to symbolic or otherwise. So, those problem can be examined in the next research.
\end{abstract}

Keywords: Translation, Representation, Unpack

Sitasi: Rahmawati, D. 2019. Translation Between Mathematical Representation: How Students Unpack Source Representation?. Matematika dan Pembelajaran, 7(1), 50-64. 


\section{INTRODUCTION}

Translation between mathematical representation is one of the important representation process that play an important role in mathematics learning. The process of representation translation helps in understanding the concept, solving the problem, and can be an indicator of learning success. If the students are able to translate various form of representation, they will have better ability in accessing the mathematic idea. Translation is a process that involve the shift and change from one representation to another form (Adu-Gyamfi et al, 2012). Bosse et al (2014) states that translation is a cognitive process in transforming the information from one representation form to another form. Ainswort (1999) says that translation is the ability to understand the connection between two forms of representation.

Translation between representation should involve two forms of representation, they are source and target of representation. Where the external representation consists of images, verbal, and kinesthetic (Fiantika, 2017). There are several translation involving more than two representations that is translation involving transition representation. In conducting translation, the students should be able to define, identify, manipulate the source, and construct the target. In the translation, people have to construct a new form that is not given, such as constructing the graph, table, or equation (Bosse et al, 2014). For the reason, it requires the ability to understand the character's component from the source and target of representation. The process of translation involves two activities, they are interpretation and construction (Leinhardt, 1990). Construction is the activity that produce a new ungiven part, such as constructing graph from the rule of function or table. Interpretation is the activity to understand the meaning from representation. Bosse's study found out that there were four activities done by the students in conducting the representation translation from graph to symbolic, they were unpacking the source, preliminary coordination, constructing the target, and determining equivalence (Bosse et al, 2014). 
Widakdo (2017) says that students' representation ability is very low. While the result of Bosse's research found out that the representation translation that involve verbal representation was the most difficult translation (Bosse et al, 2011). Bal's study also found out that students succeed in the representation translation but did not success in verbal representation (Bal, 2015). While, Gurbuz's research found out that the translation from verbal representation, table, and graph equation were the most difficult (Gurbuz et al, 2015). The same finding was found out from Rahmawati's research that the ability of representation translation from verbal to graph was still limited (Rahmawati et al, 2017).

From the researches above, it can be concluded that there are a lot of students get some difficulty in translation of verbal representation. Adu-Gyamfi et al (2011) found out that the source of error was the lack of text understanding. In the process of verbal representation translation, the ability to work with the structure of text and information character is needed. Verbal representation is a representation that has low density of information, so there will be some error. The low density of information causes the students to get difficulty in unpacking the source. Sometimes the students focus on the unimportant information and ignore the important information. The important information that is not excavated is one of the factor that influence the process of translation. Therefore, the students' activities in unpacking the source determine the success of translation process. Limited information from verbal representation demands the students to work hard in unpacking the source. However, understanding how the students unpacking the source when the translation process to maximize student success becomes a major challenge in mathematics learning.

This study describes how the students unpacking the source in conducting representation translation from verbal to graph. This study is expected to complement the previous research related to representation translation. Besides, the result of this research can be used as the consideration in arranging the learning based on the representation translation from verbal to graph, thus can maximize student success in representation translation. 


\section{METHOD}

This study is a qualitative study that aimed to describe the process of unpacking the source in conducting representation translation from verbal to graph. This study involved twenty students of mathematics education program in Universitas Negeri Malang. The purposive sampling was used to get the subject of study. The subjects were chosen based on the purpose of study, the subject should have a good communication skill in order to get better explanation in the process of unpacking the source. To take the subjects, the researcher gave the test to twenty students. The students did the test using think aloud technique. Four students were chosen as the subject of the study. The choice is based on the answer of written test and the ability to communicate.

The instrument in this study are test and interview. The researcher was the one who conduct the test and interview and did not intervene the subject of the study. The test was related to the problem in conducting the representation translation from verbal to graph. The test was validated by two experts of mathematic expert and mathematics education expert. The interview was conducted based on the result of written test. The researcher used semi-structured interview. The question of interview was used to clarify the data that was gotten from the test.

Data collecting was done by giving a test using think aloud technique. In conducting the test the students have to answer it verbally. The researcher recorded all the verbal expressions with the tape recorder and noted the students' behavior. Then, the researcher conducted the interview if there were unrevealed information. The interview was done to find out the reason of students in taking some step to solve the problem. The researcher analyze the result of the test and interview. If there were inconsitency, there would be interview again for clarification.

The data of the research was written answer, think aloud, and result of interview. Data analysis was conducted by transcribing the data, reviewing the data, and reducing or choosing the main data, focusing the important data, analyzing by coding the data, describing the data, and delivering the data in the form of narration to get the conclusion. 


\section{RESULT AND DISCUSSION}

The students were given a test about the representation translation from verbal to graph. The verbal representation used was a verbal situation, that was a real situation from an event. The students were asked to draw a graph in a cartesian coordinate. The graph represented the verbal situation given. In exposure the results of this study, it was chosen two students that are S1 and S2. Generally, the subject could do unpacking the source well. The subject unpacked the source by different activities. The process of unpacking the source was explained as follows:

\section{Analysis of Subjek 1 (S1)}

At the beginning, S1 did unpacking source by reading the question thoroughly. By reading the question thoroughly, the subject got the information given. The information was used to solve the problem. S1 observed the problem thoroughly, so the information would be memorized and understood. Then, S1 drew a scheme based on the verbal situation. S1 drew a dot that show the location of $\mathrm{X}$ city and $\mathrm{Y}$ city. $\mathrm{S} 1$ also put $\mathrm{A}$ in $\mathrm{X}$ and $\mathrm{B}$ in $\mathrm{Y}$ that show the initial position of A car in $\mathrm{X}$ city and $\mathrm{B}$ car in $\mathrm{Y}$ city. The $\mathrm{S} 1$ gave an arrow in the scheme to show the direction of the car. The right arrow showed the A car move from $\mathrm{X}$ city to $\mathrm{Y}$ city and the left arrow showed the B car move form Y city to X city. Next, S1 gave braces that show the distance from $\mathrm{X}$ city to $\mathrm{Y}$ city. The figure of the scheme was showed in the Figure 1, as follow:

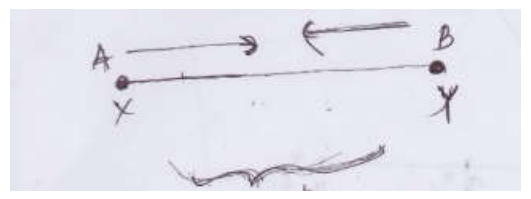

Figure 1: S1 scheme

S1 has drawn the scheme to illustrate the verbal situation based on the verbal information given. The scheme drawn shows the information understood by S1 
based on verbal information. Drawing the scheme facilitated S1 in identifying the problem.

Then, S1 stated that before the car crossing each other, the speed of A car equal to the speed of B car and after the cars cross each other the speed of A car increase two times from B car. It corresponded with S1 statement as follow:

S1: the cars cross each other (while directing the pen to the scheme) with equal speed and after they cross each other the speed of A car increase 2 time from B car.

Then S1 stated that the formula to calculate speed is $=\frac{s}{t} . \mathrm{S} 1$ connected the verbal information with concept of $V=\frac{S}{t}$. Next, S1 read the problem again. S1 stated that the problem was relationship graph between the distance and time of two cars. S1 identified again the information. It corresponded with S1 statement as follow:

S1: eeee..... what is being aksed is the relationship graph between the distance and time of two cars (by looking at the problem given)

After identifying the question, S1 was silent. S1 tried to identify other verbal information that is needed to draw a graph. S1 stated that the time is equal. S1 said the verbal information that two cars start to move at the same time. S1 has identified the new information about the time. Then, S1 was silent again. S1 tried to identify the verbal information to determine the distance of two cars. S1 paid attention to the scheme and S1 stated the new verbal information that was mileage. S1 stated that the distance of the two cars was related to the mileage. S1 decided the mileage of the two cars at first to determine the distance. The S1 statement recorded as follow:

S1: the time is equal. Eeee ... (while thinking) the mileage.

Based on the explanation above, S1 did the unpacking the source very well. S1 started by reading the question to get the information. S1 drew the scheme from verbal situation given. In the scheme, S1 identified some information in verbal representation that was known. The verbal information was A car move from $\mathrm{X}$ to 
$\mathrm{Y}$ city, $\mathrm{B}$ car move from $\mathrm{Y}$ to $\mathrm{X}$ city, the distance between $\mathrm{X}$ and $\mathrm{Y}$ city, and the speed before and after the car cross each other. Then S1 read the question again and identified other information. S1 stated another information that the two cars move at the same time. S1 identified the new information to determine the distance between two cars. The new information was the mileage and the time. S1 identified and understood the component of representation verbal very well. S1 chose the verbal information to draw a graph. The information would be transferred into the graph component. S1 also stated that the verbal information given was enough to create a graph. It showed that S1 understood well what was needed in drawing a graph.

Analysis of Subject 2 (S2)

S2 subject started unpacking the source by reading the question thoroughly. Then, S2 drew a scheme that illustrate the verbal situation. The scheme showed the information that was understood by S2. S2 made a scheme by drawing the initial point of A car in X city and B car in Y city. Then, S2 drew an arrow to show the direction of the cars. S2 put symbols $V_{A}$ and $V_{B}$ in the scheme. S2 identified important information and recognized the key information that will be used to draw a graph. The information was the A car move from $\mathrm{X}$ to $\mathrm{Y}$ city, the $\mathrm{B}$ car move from $\mathrm{Y}$ to $\mathrm{X}$ city, both of the cars move at the same time, before crossing each other the car have equal speed, after crossing each other the A car increase the speed two times and B car has the same speed as before.

Next, S2 stated that the cars cross each other at the middle of the road between $\mathrm{X}$ and $\mathrm{Y}$ city. It meant that $\mathrm{S} 2$ has connected the information with the new information. The new information would be used to solve the problem. S2 drew a dot to show the meeting point of the cars. S2 has completed the scheme with the new information. The work of S2 in completing the scheme can be seen in the figure 2 as follow: 


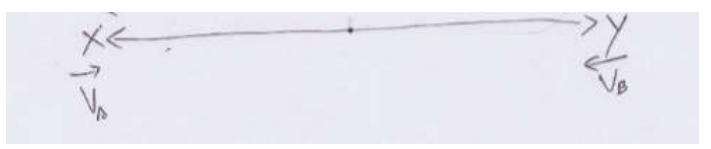

Figure 2: S2 scheme

S2 stated that the problem is drawing a relationship graph of the distance and time. S2 identified the verbal information related to the problem. The information was the distance and time. S2 has understood the problem in the question.

Based on the explanation above, S2 could do unpacking the source very well. S2 drew the verbal situation to do unpacking the source. S2 identified some information in verbal representation by drawing the scheme. The information was A car move from $\mathrm{X}$ to $\mathrm{Y}$ city, $\mathrm{B}$ car move from $\mathrm{Y}$ to $\mathrm{X}$ city, the distance between $\mathrm{X}$ and Y city, the speed after and before the cars crossing each other, the distance between two cars, the equal time. S2 has identified and understood all the component of verbal representation. S2 has chosen the verbal information to draw graph. The information in verbal representation would be transferred as the component of graph. S2 also stated that the verbal information was enough to create graph. It meant that $\mathrm{S} 2$ has understood what was needed to construct a graph.

Based on the result of this study, the students had the ability to do the unpacking the source in verbal representation. By unpacking the source, the students were able to get the important information used to construct a graph. At the beginning of unpacking the source, the students read the verbal that was given thoroughly. Second step, the students gave more attention to the problem that exist, it would enable the students to memorize and understand the information. So that, the subject could get the information that was needed in solving the problem. Sajadi (2013) states subject in reading, the reader communicates with the verbal problem to get the purpose.

After reading, the students drew a scheme related to the verbal situation. The scheme is a general description about the verbal situation. It meant that the 
students have changed the information from verbal to scheme. Verbal representation has low density of information, so it gives the possibility that there will be unrevealed information in unpacking the source. Drawing a scheme can facilitate the linkage of verbal situation. Ueska et al (2007) states that a scheme is a powerful tool in facing the verbal problem. Lavy (2007) also states that drawing a scheme will maximize the understanding of verbal problem. The students drew a scheme to help them in identifying and understanding the information in verbal representation. The same thing was stated by Mastuti (2017) that students who are able to represent a concept in the form of an image show an understanding of a concept. This result in line with the research of Dundar (2015) which states that the students successfully solving the verbal problem because they changed the situation from verbal to graph, so it will be easier to be understood.

S2 drew a scheme after reading every information in the question. The activity conducted by S2 is in line with the Stlyanou (2010) statement that drawing scheme is conducted after reading the problem. While S1 drew a scheme after reading the verbal information. Even though there was a slightly different step to draw a scheme, gradually both of the students drew the scheme based on the sequence of information.

The students drew the scheme to illustrate the verbal information which was understood. Stylinou (2010) states that drawing a scheme as the extension of memory work and the summary of the information. Drawing scheme will reduce the cognitive load toward the storage of memory. This theory is in line with the Schnoutz (2002) statement that illustrating a text to a graph elps students to memorize the information. This means that there is a link between the scheme with the understanding of situation.

Both of the students drew a scheme as an effort to reveal the information. It is based on the interview, the students stated that the scheme was made to make the information clearer. Both of the students realized that drawing a scheme facilitated them to identify and understand the problem. The result is in line with Poch et al 
(2015) statement that in process of translation there should be an awareness in drawing the scheme to helps them solve the verbal problem. The activity done by the students gives a characteristic in the process of verbal representation translation. The activity is also in line with Hegarty et al (1999) and Fennel et al (2000) which state that drawing scheme can help the students to describe the information and analyze the relation between the information and problem. Besides, drawing scheme can help the students in understanding the problem and memorize the information (Stylianou, 2010; Tversky, 2001).

Based on the graph, the students identified relevant information in verbal representation. S1 identified that the A car moves from $\mathrm{X}$ to $\mathrm{Y}$ city, B car moves from $\mathrm{Y}$ to $\mathrm{X}$ city, the distance between $\mathrm{X}$ and $\mathrm{Y}$ city, the speed before and after the cars cross each other, the distance between two cars. While S2 identified that A car moves from $\mathrm{X}$ to $\mathrm{Y}$ city, B car moves from $\mathrm{Y}$ to $\mathrm{X}$ city, the cars move at the same speed, after crossing each other the speed of A car increases two times and the speed of B car is the same. In the process of translation, the students have to differentiate the relevant and irrelevant information (Duval, 2006). The information will be used in the next process that is constructing the component of graph.

Besides, the students did unpacking the source by interpreting the verbal information. The ability to interpret the information is needed in solving the problem. This activity facilitates the students in understanding the information and finding the strategy in solving the problem. The student interpreted by stating the information on their own language. Krawec (2010) states that the paraphrase is a repeating statement of verbal information gives meaning in different form.

The students have identified and understood all the information given even if not all of the information was written explicitly. The students have chosen the relevant information to be used in the next step. The students also have analyzed the information that will be used to draw the graph. Based on the interview, the students stated the information given has been understood and was enough to draw a graph. By knowing the adequacy of information, the students have understood the question and known the strategy used to draw a graph. Therefore, the students can 
determine the fundamental idea that will be used in the next step. Both of the students have conducted unpacking the source very well, that was shown by the understanding of all verbal information. Verbal information that is identified and understood will be transferred to be components of graph.

Based on the description above, students perform the same activity but different sequences when unpacking the sourceThe process of unpacking the source by $\mathrm{S} 1$ and $\mathrm{S} 2$ can be seen in the figure 3 and 4 as follow:

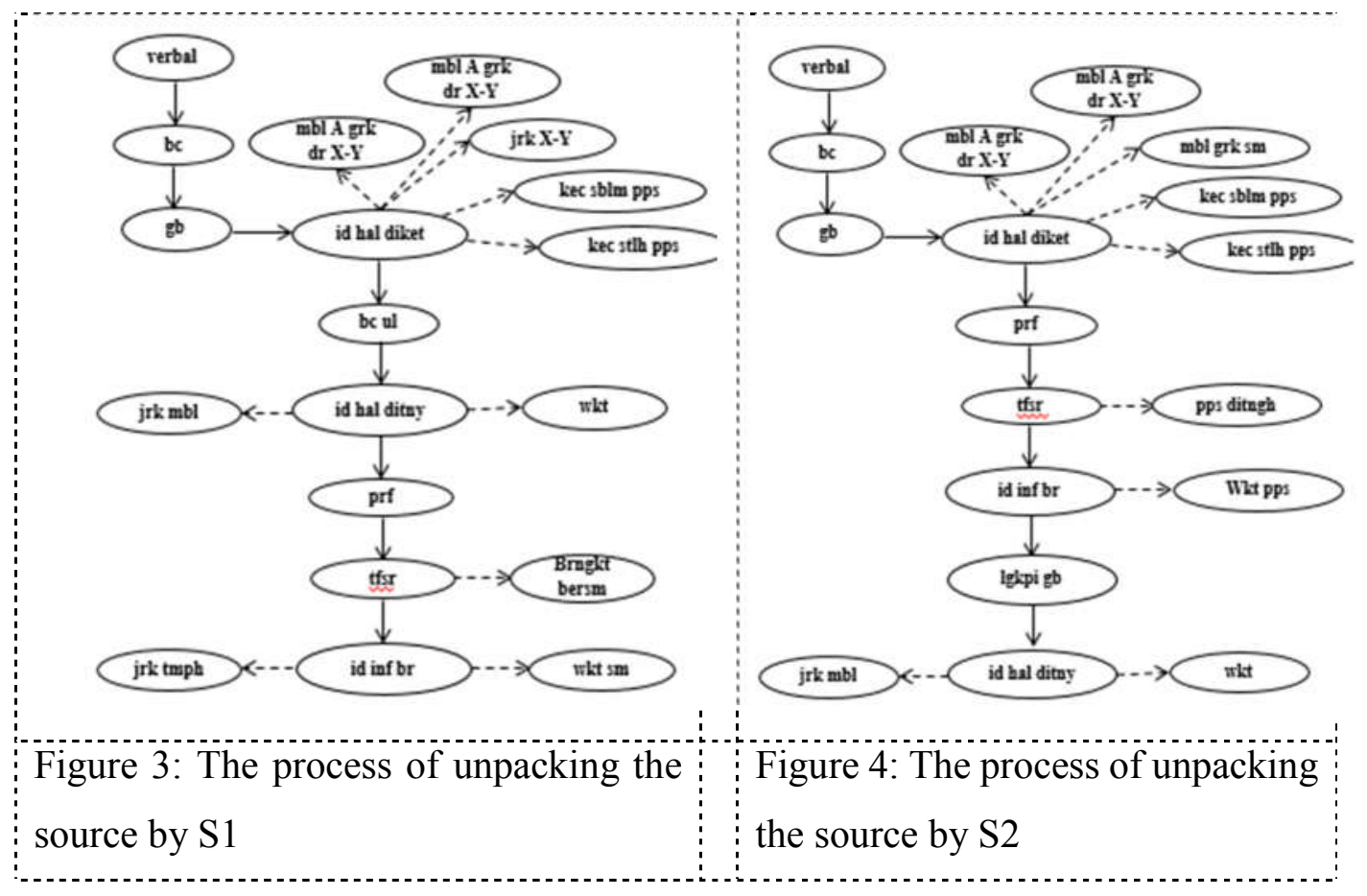

Table 1: The code term in the process of unpacking the source

\begin{tabular}{ll}
\hline \multicolumn{1}{c}{ Code } & Term \\
\hline Verbal & Verbal Representation \\
$\mathrm{Bc}$ & Read the question \\
$\mathrm{Gb}$ & Draw verbal situation \\
id hal diket & identify the things known \\
\hline
\end{tabular}




\begin{tabular}{|c|c|}
\hline Code & Term \\
\hline mbl A grk $r$ & A car move from $\mathrm{X}$ to $\mathrm{Y}$ city \\
\hline $\mathrm{X}-\mathrm{Y}$ & \\
\hline mbl A grk r & $\mathrm{B}$ car move from $\mathrm{Y}$ to $\mathrm{X}$ city \\
\hline $\mathrm{X}-\mathrm{Y}$ & \\
\hline jrk X-Y & The distance between $\mathrm{X}$ and $\mathrm{Y}$ city \\
\hline kec sblm pps & before crossing each other the cars have equal speed \\
\hline kec stlh pps & After crossing each other the speed of A car increase two times \\
\hline & from B car and the speed of the B car is the same as before \\
\hline bc ul & Read the question again \\
\hline id hal ditny & identify the things asked \\
\hline jrk mbl & The distance of two cars \\
\hline Wkt & Time \\
\hline Prf & State the information again \\
\hline brngkt sm & The cars move at the same time \\
\hline Tfsr & Interpret the given information \\
\hline id inf br & Identify the new information \\
\hline jrk tmph & Mileage \\
\hline mbl grk sm & The cars move at the same time \\
\hline wkt sm & Equal time \\
\hline pps ditngh & $\begin{array}{l}\text { The cars cross each other at the middle of the road between } \mathrm{X} \\
\text { and Y city }\end{array}$ \\
\hline wkt pps & Time of crossing each other \\
\hline lgkpi gb & Complete schema \\
\hline
\end{tabular}




\section{CONCLUSION}

In the process of unpacking the source the students did the same activities but in a different order. The activities were reading the problem thoroughly, drawing a scheme from the verbal illustration, identifying the information, identifying the problem, understanding the verbal information, and identifying the new information. The figure of the scheme from verbal situation helped the students in unpacking the source and understanding the verbal situation. The success in unpacking the source supported the next step in solving the problem of representation translation. This research is only limited to the process of unpack verbal representation in translation from verbal to graph and has not been able to provide a description for the reverse translations nor for other types of representation and have not described the process of unpack other types of representation. further research related to this is still very open to do.

\section{REFERENCE}

Adu-Gyamfi K., Bosse, M.J. and Stiff, L.V. (2012). Lost in Translation: examining translation errors assosiated with mathematical representation. School science and Mathematics, 112(3), 159-70.

Adu-Gyamfi, K., Bosse, M.J\& Chandler, K. (2015). Situating student errors: linguistic-to-algebra translation errors. International Journal for Mathemathics Teaching and Learning, 1-29.

Ainsworth, S. (1999). The function of multiple representations Computer and Education. 3(3), 131-52.

Bal, A.P. (2015). Skills of using and transform multiple representations of the prospective teachers., Social and Behavioral Sciences., 19(7), 582-8.

Bosse, M.J., Adu-Gyamfi, K\& Cheetham, M.R. (2011)Assesing the difficulty of mathematical translations: synthesizing the literature and novel., International Electronical Journal of Mathematics Education., 6(3), 113133.

Bosse, M.J., Adu-Gyamfi, K\& Chandler, K. (2014). Students differented translation processes, $27 \quad$ Maret 2016, http://www.cimt.plymouth.ac.uk/journal/bosse5.pdf.

Fiantika, F.R. (2017). Representation elements of spatial thinking Journal of physics: Conf. Series., 824. 
Dundar, S. (2015). Mathematics teacher-candidates performance in solving problem with different representation style: the trigonometry example. Eurasia Journal of Mathematics, Science \& Technology Education, 11(6), 1379-1397.

Duval, R. (2006). A cognitive analysis of problems of comprehension in a learning of mathematics. Educational Studies in Mathematics, 6(1), 103-31.

Fennel, F\& Rowan, T. (2000) Representation: an important process for teaching and learning mathematics (2000), 3 Maret 2016, https://www.researchgate.net/publication/234581020.

Gurbuz, R\& Sahin, S. (2015). 8th grade students skill in translating among multiple representations. K. U. Kastamonu Egitim Dergisi., 23(4), 1865-1884.

Hegarty, M\& Kozhevnikov, M. (1999). Types of visual-spatial representations and mathematical problem solving. Journal of Educational Psychology 91(4), 684-689.

Krawec, J.L. (2010). Problem representation and mathematical problem solving of students of varying math ability (doctoral dissertation) Miami: University of Miami, 7 Februari 2016, http://scholarlyrepository.miami.edu/cgi/viewcontent.cgi?article=1454\&c ontext $=$ oa dissertations.

Leinhardt, G., Zaslavsky, O\& Stein, M.K. (1990) Function, graphs, and graphing: task, learning, and teaching Review of Educational Research., 60(1), 1-64.

Lavy, I.,A. (2007). Case study of dynamic visualisation and problem solving. International Journal of Mathematical Education in Science and Technology., 38(8), 1075-1092.

Mastuti, G. A. (2017). Representasi Siswa Sekolah Dasar Dalam Pemahaman Konsep Pecahan. Matematika dan Pembelajaran, 5(2), 193-208

Poch, A.L., Garderen, D.V\& Scheuermann, A.M. (2015). Students' understanding of diagrams for solving word problems: a framework for assessing diagram proficiency., Teaching Exceptional Children, 4(7), 153-62.

Rahmawati, D\& Anwar, R.B. (2017). Translasi representasi matematis verbal ke grafik pada materi fungsi Prosiding Seminar Nasional Integrasi Matematika dan Nilai Islam, 557-63.

Sajadi, M., Amiripour, P\& Malkhalifeh, M.R. (2013). The examining mathematical word problem solving ability under efficient representation aspect., Mathematics Education Trends and Research 2013, 1-11.

Schnotz, W. (2002) Commentary: Towards an integrated view of learning from text and visual displays Educational psychology review, 14(1), 101-120.

Stylianou, D.A. (2010). Teachers' conceptions of representation in middle school mathematics., Journal of Mathematics Teacher Education, 13, 325-343.

Tversky, B. (2001). Spatial schemas in depictions in Gattis, M (Ed.). Spatial schemas and abstract thought 79-112. Cambridge, MA: MIT Press.

Uesaka, Y., Manalo, E\& Ichikawa, S.I. (2007) What kinds of perceptions and daily learning behaviors promote students' use of diagrams in mathematics problem solving?., Learning and Instruction., 17(3), 322-35. 
Rahmawati, D. 2019. Translation Between Mathematical Representation... Matematika dan Pembelajaran, 7(1), 64 of 64

Widakdo, W.A. (2017). Mathematical representation ability by using project based learning on the topic of statistics., Journal of physics: Conf. Series 895. 